\title{
Can You Teach Old Dogs New Tricks? On Complementarity of Human Capital and Incentives
}

\author{
Jana P. Fidrmuc* \\ Warwick Business School, University of Warwick, Coventry, CV4 7AL, United Kingdom.
}

\section{Jan Fidrmuc}

Economic and Finance, Brunel University, Uxbridge, UB8 3PH, United Kingdom; Centre for Economic Policy Research (CEPR), and William Davidson Institute

(WDI), University of Michigan

\section{October 2005}

\begin{abstract}
:
Contract theory suggests that firm performance can be improved by appointing new managers and/or by introducing better incentives. Furthermore, these two changes should be complementary - their effects reinforce each other. Using data on privatized firms in the Czech Republic, this paper presents results that suggest complementarity between the appointment of new managers and introduction of incentives in a transition economy. The results also show that ignoring the complementarity may lead to the wrong conclusion that the effect of incentives is weak. Managerial incentives seem to work only after the new post-privatization managers are appointed.
\end{abstract}

JEL Classification Numbers: G34, L29, M51, P31

Keywords: Contract Theory, Incentives, Managerial Change, Privatization, Restructuring.

* Corresponding author. E-mail: Jana.Fidrmuc@wbs.ac.uk, Phone: +44-2476-522-210, Fax: +44-2476-523-779. 


\section{Introduction}

This paper analyzes managerial replacement as a tool that new private owners can use to improve firm performance after privatization. In general, firm performance depends on both managerial ability and efforts (Laffont and Tirole, 1986). To induce the manager to increase effort, the owner (the principal) can introduce incentives such as performance-dependent pay/bonuses, promotion/reappointment if performance is good and demotion/dismissal if it is bad. Thus, theory predicts that firm performance can be improved in two ways: by appointment of more capable managers or by introduction of stronger incentives. However, McAfee and McMillan (1987) argue that these two instruments are in fact complementary so that new managers and better incentives reinforce each other. The complementarity of human capital and incentives plays an especially important role during the post-communist transition:

"Reforms are interlinked. The various incentive mechanisms that constitute a market system can complement or substitute for each other. ... [S] tronger incentives and better managers are complementary changes. They might be so complementary that neither change would be effective by itself. Some managers might be so inadequate as to be unable to respond to new incentives, no matter how well designed. Good managers might not work well under badly structured incentives. If so, restructuring is effective only if both changes - new managers and new incentives - are introduced together." [McMillan, 1997, pp. 210 and 215].

Managerial incompetence and lack of motivation constitute two important sources of inefficiency of state firms in a planned economy. Thus, firm restructuring should focus both on the introduction of stronger incentives and on appointment of competent managers (McMillan, 
1997, and Roland, 2000). But which one of the two should receive priority? So far, empirical evidence on restructuring in transition is predominantly in favor of the view that the new human capital is more important than incentives. ${ }^{1}$ Often, introduction of new managers is associated with better firm performance whereas the evidence for incentives is weak. However, failure to account for the complementarity between human capital and incentives may lead to misleading conclusion that better incentives do not work and that the appointment of new managers is more important.

Our paper sheds some new light on the relative roles of human capital and incentives and interactions between them in firm restructuring. Compared to the previous literature ${ }^{2}$, we employ the approach often used in the finance literature that examines the sensitivity of managerial change to past firm performance (see, for example, Denis and Denis, 1995). ${ }^{3}$ This methodology addresses the impact of negative incentives embodied in high sensitivity of managerial change to poor past performance. We find that the negative managerial incentives start working only after the incumbent pre-privatization manager has been replaced by a new, presumably more competent manager. In particular, our analysis shows that the first post-privatization managerial change is not sensitive to poor past performance. In contrast, poor past performance significantly increases the probability of manager's dismissal for the second and subsequent changes of the top manager (in firms where the new private owners had already introduced a new manager). This indicates that the new incentives kick in only after the first post-privatization managerial change, which suggests that human capital and incentives are indeed complementary.

\footnotetext{
${ }^{1}$ See, for example, Barberis et al. (1996), Claessens and Djankov (1999), Djankov and Murrell (2002), Warzynski (2003) and Fidrmuc and Fidrmuc (2004).

${ }^{2}$ Claessens and Djankov (1999) and Groves et al. (1995), for example, explore the impact of managerial changes on future firm performance.

${ }^{3}$ Other papers include, for example, Weisbach (1988), and Warner et al. (1988), for a review of empirical papers see Hermalin and Weisbach (2003), and John and Senbet (1998).
} 
One important shortcoming of the paper is that we do not have data on positive incentives of managers, such as their remuneration package. Results that would show that only the new postprivatization managers respond positively to performance-sensitive remuneration would provide even stronger support for the hypothesis of complementarity between incentives and new human capital. Unfortunately, such data are not available. Nevertheless, we believe that our results, while falling short of giving indisputable proof, nonetheless provide convincing suggestive evidence in support of complementarity, and will hopefully motivate future research with more suitable data.

The theory predicts that complementarity of managerial talent and incentives is a general economic phenomenon (McAfee and McMillan, 1987, and Laffont and Tirole, 1986). Therefore, we believe that our results suggesting that the new managers and incentives are complements, although obtained in the specific conditions of a transition economy, could be generalized for broad economic conditions. Nevertheless, we would like to note that transition provides a unique quasi-experimental setting for our test. In transition, all existing state-owned enterprises experience a simultaneous shock and are, therefore, induced to restructure at the same point in time. They are all generally inefficient, in need of better managers and better incentives, and face the same general economic conditions. Furthermore, all firms in our data set were privatized through the Czech voucher privatization program. This provides us with uniquely suitable empirical setting and simplifies the analysis.

The article proceeds as follows. Section 2 introduces the data. Section 3 shows basic univariate results supporting complementarity of incentives and human capital. Even though the full sample results indicate only weak support for negative incentives in the form of low sensitivity of managerial change to poor past performance, a more detailed analysis reveals that after the new post-privatization managers are introduced, further managerial changes are 
sensitive to past performance. Regression analysis in Section 4, confirms this result. Section 5 concludes.

\section{Data}

We carry out our analysis with a panel of 923 non-financial firms privatized during the two waves of voucher privatization in the Czech Republic. ${ }^{4}$ The data span the period from 1993, the year when ownership rights were transferred after the first wave of voucher privatization, to 1998. It is important to note that we study the former state-owned enterprises from the moment they were privatized and, therefore, we are able to observe and analyze all changes introduced by the new private owners. We concentrate on voucher-privatized companies, as the voucher privatization constituted the main privatization channel in the Czech Republic, accounting for around 50 percent of total book value of the assets privatized in the large-scale privatization. ${ }^{5}$ Moreover, the fact that all voucher-privatized firms were listed on a stock exchange immediately after the privatization means that data are readily available and their quality is relatively good.

The basic criterion for a firm to be included in our analysis is that information on its sales, fixed assets, number of employees, and costs of goods sold must be available for at least 3 years. The data set contains also various non-economic information about the firms. Importantly, we are able to identify the firm's managing director and the date he or she assumed this position. ${ }^{6}$ Unfortunately, the data have some limitation too. We have no information on the managing director's professional qualifications (education, experience, and employment history within and outside the firm) or the reasons for the managing director's departure. Therefore, while we can

\footnotetext{
${ }^{4}$ The data were purchased from Aspekt Kilcullen s.r.o. (http://www.aspekt.cz/).

${ }^{5}$ For more details on the Czech privatization program see Fidrmuc et al. (2002).

${ }^{6}$ In the Czech Republic, the managing director is usually referred to as the general director or the general managing director.
} 
observe changes of the managing director, we do not know whether the previous managing director was dismissed or whether he left for other reasons (such as health problems, retirement, death, or because of moving to another firm). Yet, as the descriptive statistics discussed in greater detail below show, changes within the top management are so frequent (ranging between 10 and 25 percent per year) that health and demographics could only account for a small fraction of them. ${ }^{7}$ Moreover, including managerial change other than dismissal would only weaken our results, as discussed below. So, in case we find a significant association between past performance and the change of the managing director, our conclusion concerning the presence of managerial incentives should be on the safe side.

We are interested in the sensitivity of managerial changes to poor past firm performance. Presence of managerial incentives should imply that managers of poorly performing firms are at a greater risk of dismissal. We use four measures of performance: labor productivity (total sales over total number of employees), gross profit per employee (total sales minus cost of sales over total number of employees), return on assets (total sales minus cost of sales over total assets) and labor productivity growth. ${ }^{8}$ Table 1 shows the summary statistics. To adjust for inflation, values of all the variables (except for number of employees and MD change) are reported in constant prices of 1993. As Panel A shows, the data set includes numerous outliers that may bias our results. In particular, these small and large sales observations could be due to errors or abnormal developments (e.g. among the smallest companies could be firms undergoing bankruptcy proceedings with essentially no on-going business activities, among the largest firms could be those that reported high sales due to creative accounting). Therefore, we exclude all firm-year

\footnotetext{
${ }^{7}$ It is also not very probable that these high replacement rates were a consequence of low turnover in the preprivatization period. In fact, Claessens and Djankov (1999) report that at least 50 percent of voucher-privatized firms in their sample replaced their managing director already in the pre-privatization period.

${ }^{8}$ Labor productivity is the prevalently used performance measure for transition countries (Earle and Estrin, 1998, Pohl et al., 1997, Frydman et al., 2002, and Linz and Krueger, 1998, among others).
} 
observations below the $5^{\text {th }}$ percentile and above the $95^{\text {th }}$ percentile for total sales. Nevertheless, we also replicated our analysis with the full data set and our findings remained unchanged. We also exclude observations with zero costs of goods sold. The statistics for the trimmed data set are shown in Panel B of Table 1. ${ }^{9}$ The exclusion of observations with very small or very large total sales decreases the total number of observations from 4109 to 3699 , the number of firms from 923 to 866 , and it brings the mean values considerably closer to the median values for all variables. Total sales still take a wide range of values - from CZK 23 million to CZK 3,385 million.

Panel B shows that an average firm produces CZK 424 million of total sales per year (in constant prices of 1993) and reports CZK 320 million as the costs of goods sold. Thus, the average inflation adjusted gross profit per year is CZK 104 million. On average, costs of goods sold constitute three quarters of total sales, leaving 25 percent for the gross profit margin. About 3 percent of the observations have a negative gross profit margin. The first two efficiency measures (labor productivity and gross profit per employee) indicate that one employee on average produces CZK 531 thousand of total sales and CZK 151 thousand of gross profit margin per year. The average return on assets is 22 percent. Moreover, Panel $\mathrm{C}$ of Table 1 shows that labor productivity (in constant prices of 1993) increases from 1993 till 1997. Gross profit per employee reaches a minimal value in 1995 and increases thereafter.

Our main focus is on the pattern of managerial turnover in the post-privatization period. Compared to available estimates of 7.8 percent - 9.3 percent for established public U.S. firms (Claessens and Djankov, 2000) and 11.8 percent for U.K. firms (Cragg and Dyck, 1999),

\footnotetext{
${ }^{9}$ The data we use in the analysis below are not inflation adjusted as this aspect of the data is taken care of by year-by-year industry adjustment and time dummies. The statistics in Table 1, however, are reported in constant prices so that the summary statistics give a reasonable picture of the development over time. This disparity means that the values of total sales for the $5^{\text {th }}$ and $95^{\text {th }}$ percentiles in Panel A of Table 1 do not correspond to the minimum and maximum for total sales in Panel B.
} 
turnover of the managing director in the Czech Republic seems relatively high. In our sample, the average turnover of the managing director is 16.8 percent per year (last row in Panel B). Panel C indicates that the turnover is relatively low immediately after the transfer of ownership and then increases up to its peak value of 25.2 percent in 1997. In total, as much as 52 percent (450 out of 866) of firms replaced their managing director during the 6 years since privatization. In most cases (313 firms), the managing director was replaced only once, while 137 firms experienced two or more managerial changes (see Panel D of Table 1). On average, the first change of the managing director took place in the forth year after the transfer of ownership in firms that replaced their managing director at least once. Similarly high top managerial turnover is reported for newly privatized firms in the U.K. (15.4 percent, Cragg and Dyck, 1999) and in East Germany (around 20 percent, Dyck, 1997).

\section{Univariate results}

As a first step in our analysis, we show simple univariate results to provide intuition for the correlation between past performance and the probability of managerial change. Figure 1 compares average performance for two types of firm-year observations: observations without a managing-director change in the following year and observations in the year immediately preceding the change of the director. We use two of the four measures that are also used in the regression analysis discussed below, labor productivity and gross profit per employee. They span over the period of 1993 to 1997 and are adjusted for industry and time (dividing by the industry average in the given year).

If negative incentives are in place, we should see a negative correlation between managerial change and past firm performance. Poorly performing managers should be at a greater risk of 
dismissal. Hence, the average performance for firm-year observations without managerial change in the following year should be higher compared to those followed by a manager change. Figure 1 indicates that this is not the case for labor productivity. On the contrary, the average labor productivity is higher in the years that are followed by a replacement. The difference is, however, not statistically significant. For gross profit per employee, the difference is in the expected direction but is not significant either. Thus, this simple test indicates that the managing director change is insensitive to past performance. Therefore, there is seemingly no evidence for the existence of negative managerial incentives in the privatized firms.

This lack of evidence for the sensitivity of managerial change to poor past performance may be due to the complementarity between new managers and incentives. If that is the case, then the introduction of new managers and incentives will be effective only once both have been introduced. Thus, in Figures 2 and 3, we partition our sample into five groups. First, we distinguish firms without any change of the managing director until 1998 (when our data ends). This is represented by the first bar. Then, for the firms with at least one managerial change, we present average performance figures for the years before the first post-privatization managerial change (second bar), the year of the first change (third bar), all observations without a change of the managing director that follow after the first change (fourth bar) and, finally, years during which the second and following managerial changes took place (fifth bar). Note that performance is measured in the year preceding the managerial change.

Figure 2 shows average values of labor productivity for the five groups. It shows that labor productivity is, on average, the lowest in the firms that did not experience any managerial change (first bar). The first two bars compare (industry adjusted) labor productivity before any change of the managing director takes place in firms where such a change follows in the near future versus firms where change never occurs (within our sample). In the presence of negative incentives, it is 
natural to expect that firms that are about to experience a managerial change in the future should perform worse than the firms where the manager does not change. However, our data do not provide evidence for such a relationship. In fact, the firms that never change their managing director underperform those that experience a change. The difference of 8.1 percent is significant at the 5-percent level. The managerial incentives in these firms thus seem to be weak.

Now, let's look at the difference in performance between the second and third bars that illustrates the performance-turnover relationship for the first change of the managing director. Again, we expect that the average performance immediately preceding managerial change (third bar) should be lower than the average performance in the no-change years (second bar). However, the third bar is in fact higher, although, the difference of 2.4 percent is not statistically significant. Still, this shows again that managerial change is insensitive to poor past performance. In contrast, the last two bars in Figure 2 indicate a relationship in the expected direction. The second (and subsequent) change of the managing director is preceded by relatively low labor productivity in the fiscal year immediately before the change. Even though the difference of 9 percent is not statistically significant, it is quite large and indicates that after the new postprivatization manager is introduced, proper negative incentives are starting to work. The new manager thus has a higher probability that he is fired if he performs relatively poorly.

To summarize, the simple analysis provided in Figure 2 (for labor productivity) shows three important facts. First, firms without any managerial change have on average lower labor productivity. Their managers are not fired even though they perform poorly. Second, the first post-privatization managerial change is not sensitive to lower labor productivity in the previous fiscal year. This shows that the pre-privatization incumbent managers are not punished for their poor performance, they are simply replaced by new managers. In contrast, however, our third result indicates that the new post-privatization managers tend to be punished by replacement in 
case they perform poorly. These three findings and the results in Figure 1 suggest that managerial incentives seem to work only after the privatized firms introduce new managers. Thus, it seems that new managers and negative incentives are quite strong complements.

Figure 3 reports analogous figures for gross profit per employee. The general pattern is similar to that in Figure 2. Firms without a managerial change perform relatively poorly. However, now the difference between the first and the second bars is not significant. The difference between the second and the third bars is in the expected direction. Nonetheless, the difference of 5.9 percent is not significant. However, the difference of 18.5 percent between the last two bars is very large and significant at the 5 percent level. On the whole, Figure 3 again supports the notion that negative incentives in the form of punishment for poor past performance get stronger after new managers are in place in the privatized firms.

\section{$4 \quad$ Regression results}

To obtain a more precise insight into the possible inter-dependence between negative incentives and human capital in privatized firms, we turn to regression analysis. We use conditional fixed-effects logit. The dependent variable is a dummy that measures changes of the managing director: it is equal to one if the managing director is changed in the given firm-year and equal to zero otherwise. As we are interested in how past performance can predict probability of the managing-director change, this dummy is regressed on lagged firm performance. We use four performance measures: labor productivity, gross profit per employee, return on assets, and labor productivity growth. All regressions control for firm size, variation in time and (fixed) firm 
effects. All the performance variables and size are adjusted for industry and time-specific fixed effects. ${ }^{10}$

First, we test for the presence of managerial incentives without distinguishing between the first post-privatization managerial change and the subsequent changes. The results in Panel A of Table 2 confirm the univariate results from Figure 1. Neither of the performance variables is significantly correlated with managerial change. It seems that the managing director is replaced regardless of firm performance and the managerial change thus does not appear to have a disciplining role.

To find out whether stronger incentives are in place once the new post-privatization managers are introduced in the firms, the regressions in Panel B of Table 2 are augmented by a variable that measures performance in firms that had already experienced their first post-privatization change of the managing director. ${ }^{11}$ This allows us to test whether the relationship between past performance is different for the first change and for the second and subsequent changes (or, in other words, whether there is a structural break in this relationship after the first change). The notion of complementarity predicts that incentives should be strengthened after the appointment of new managers. Thus, we expect the performance-turnover sensitivity to be higher (more negative) in the second part of the sample.

Panel B of Table 2 suggests that new managers and incentives are indeed complementary. Model 5 documents that labor productivity is not significantly correlated with the probability of managerial replacement for the first post-privatization change of the managing director. This indicates that $\mathrm{CEO}$ dismissal does not serve as a disciplining tool. The variable measuring the relationship for the second and subsequent changes, however, is negative, significant at the 1-

\footnotetext{
${ }^{10}$ In particular, each firm-year observation is divided by the industry average in the given year.

${ }^{11}$ This variable is equal to the respective performance measure for all firm-year observations following the first managerial change in the given firm, and zero otherwise.
} 
percent level and large. Hence, the performance-turnover relationship changes from insignificant to significantly negative after the first post-privatization manager is introduced. The overall performance effect after the first change of the managing director (reported in the last row of Panel B) is negative and significant at the 1-percent level. Results for gross profit per employee, return on assets, and labor productivity growth in Models 6-8 are almost identical. Hence, after the new private owners introduce new managers, managerial incentives get stronger.

Our results appear robust also to changes in regression specifications. In particular, we replicated the analysis also with two lags of labor productivity instead of one as well as with only the second lag of performance. Taking longer or multiple lags should help account for the fact that the relationship between performance and managerial change may be of a longer-term nature. Furthermore, since some firms have experienced more than one managerial change in close succession, the performance in the year immediately preceding the replacement of managing director may have been affected by an earlier managerial change. ${ }^{12}$ The results, however, are insignificant, just as those with only the first lag of performance. As a further robustness check, we replicated the analysis with the full data set, i.e. without dropping the smallest and largest 5 percent of firms. The results are again essentially the same as those discussed above (see the Appendix at the end of the paper).

It is important to relate our findings to the previous empirical evidence, especially the findings of Claessens and Djankov (1999 and 2000). They relate managerial changes to subsequent firm performance for a very similar set of Czech voucher-privatized firms. Their main conclusion is that it is the new human capital that brings about improvements in corporate performance in transition economies. We approach the issue form a slightly different perspective.

\footnotetext{
${ }^{12} \mathrm{We}$ are grateful to a referee to suggesting this possibility. The results are available upon request.
} 
While our findings are not inconsistent with theirs, we extend and widen the analysis by specifically addressing the interdependence between new human capital and incentives. Hence, while we confirm the importance of introducing new human capital into privatized firms, we argue that it is especially human capital and incentives introduced together that improve performance.

An alternative explanation of our findings is that the first managerial change signifies that the new owners take control of the firm. Accordingly, incentives are introduced only when the new managers are appointed: we find little evidence of negative incentives before the change because the incentives were not in place yet. Given that the bulk of managerial changes take place during the last three years of our data, this would imply that the new owners wait for two to three years before actually taking control. Even more worryingly, almost half of the firms do not replace their managing director during the period that we observe. Even taking account of the fact that the Czech voucher privatization often resulted in relatively widely dispersed ownership of privatized firms, we think it unlikely that owners would fail to exercise their influence over the firms for that long. Therefore, while our data are not detailed enough to allow us to discriminate between these two alternative hypotheses, we find the explanation based on complementarity more appealing.

\section{Conclusions}

In this paper, we provide empirical evidence on complementarity between new managers and managerial incentives. According to contract theory (for example models by Laffont and Tirole, 1986, and McAfee and McMillan, 1987), firm performance is a function of manager's ability and effort. Therefore, both appointment of new managers and introduction of new incentives should 
lead to improved firm performance. An important feature of the two changes, however, is that they may work as complements and reinforce each other. If that is the case, the effect of either change becomes stronger after the other change has been also introduced.

This paper provides evidence suggesting there is indeed complementarity between human capital and incentives in privatized firms in the Czech Republic. We show that the relationship between past performance and managerial turnover strengthens after the appointment of the first post-privatization managing director. Before the first managerial change, past performance has no bearing on the probability of managerial turnover, indicating weak disciplining role of CEO replacements. After the change, however, past firm performance turns to be negatively and significantly correlated with the probability of managerial change. Moreover, our data show that firms without a change of the managing director over the 6 years after the privatization perform worse than the firms that replaced their managing directors. We interpret these findings as evidence suggesting that the appointment of new managers and introduction of incentives are strongly complementary changes. Managerial replacements seem not to work as disciplinary tools (negative incentives) before the new manager is introduced. Thereafter, however, the managers who perform poorly are at a higher risk of replacement.

Empirical studies on human capital and incentives in transition tend to conclude that the new human capital is more important than the new incentives. Our analysis suggests that the failure of previous studies to find evidence on the impact of managerial incentives may be a direct consequence of the strong complementarity between the two changes. Taking complementarity of new managers and incentives into account may lead to different conclusions. 
Acknowledgements

We are grateful to Christoph van der Elst, Grzegorz Trojanowski, Luc Reneboog, Marno Verbeek, participants in seminars at Rotterdam School of Management, WIFO, Chongqing, ICCEES Conference in Berlin, Emerging Markets Finance Conference at Cass Business School, as well as Kate Phylaktis as the editor and an anonymous referee for many helpful comments and suggestions. Jan Fidrmuc was a Marie Curie Fellow at ECARES, Université Libre de Bruxelles, while this research was initiated. Financial support from the European Union and the hospitality and research support of ECARES is gratefully acknowledged. 
APPENDIX: FULL SAMPLE REGRESSIONS

\begin{tabular}{|c|c|c|c|c|c|c|c|c|}
\hline \multirow{3}{*}{ Panel A: Pooled regressions } & \multirow{2}{*}{\multicolumn{2}{|c|}{$\begin{array}{c}\begin{array}{c}\text { Labor } \\
\text { productivity }\end{array} \\
\text { Model } 1\end{array}$}} & \multicolumn{2}{|c|}{$\begin{array}{l}\text { Gross prof. per } \\
\text { employee }\end{array}$} & \multicolumn{2}{|c|}{ Return on assets } & \multicolumn{2}{|c|}{$\begin{array}{l}\text { Labor productivity } \\
\text { growth }\end{array}$} \\
\hline & & & \multicolumn{2}{|c|}{ Model 2} & \multicolumn{2}{|c|}{ Model 3} & \multicolumn{2}{|c|}{ Model 4} \\
\hline & coef. & s.e. & coef. & s.e. & coef. & s.e. & coef. & s.e. \\
\hline Performance (lagged) & -0.153 & 0.118 & -0.050 & 0.056 & 0.043 & 0.078 & 0.124 & 0.118 \\
\hline Size (lagged) & -0.008 & 0.020 & -0.008 & 0.020 & -0.008 & 0.020 & -0.064 & 0.054 \\
\hline Fixed effects & yes & & yes & & yes & & yes & \\
\hline Year dummies & yes & & yes & & yes & & yes & \\
\hline \# of observations & 4109 & & 4109 & & 4109 & & 3156 & \\
\hline \# of firms & 923 & & 923 & & 923 & & 922 & \\
\hline$\chi^{2}$ & 95.54 & $* * *$ & 94.36 & $* * *$ & 93.86 & $* * *$ & 47.09 & $* * *$ \\
\hline \multirow[t]{2}{*}{$\begin{array}{l}\text { Panel B: First versus subsequent } \\
\text { changes }\end{array}$} & \multicolumn{2}{|c|}{ Model 5} & \multicolumn{2}{|c|}{ Model 6} & \multicolumn{2}{|c|}{ Model 7} & \multicolumn{2}{|c|}{ Model 8} \\
\hline & coef. & s.e. & coef. & s.e. & coef. & s.e. & coef. & s.e. \\
\hline Performance (lagged) & 0.351 & $0.153 * *$ & 0.230 & $0.091 * *$ & 0.330 & $0.107 * * *$ & 0.645 & $0.178 * * *$ \\
\hline Performance after the first MD change & -2.213 & $0.182 * * *$ & -1.380 & $0.138 * * *$ & -1.469 & 0.137 & -3.498 & $0.240 * * *$ \\
\hline Size (lagged) & 0.008 & 0.026 & 0.023 & 0.031 & -0.009 & 0.020 & -0.035 & 0.048 \\
\hline Fixed effects & yes & & yes & & yes & & yes & \\
\hline Year dummies & yes & & yes & & yes & & yes & \\
\hline \# of observations & 4109 & & 4109 & & 4109 & & 3156 & \\
\hline \# of firms & 923 & & 923 & & 923 & & 922 & \\
\hline$\chi^{2}$ & 326.90 & $* * *$ & 233.56 & $* * *$ & 242.33 & $* * *$ & 366.24 & $* * *$ \\
\hline $\begin{array}{l}\text { Test of joint significance: } \\
\text { perf. + perf. after } 1^{\text {st }} \text { MD change }\end{array}$ & $\begin{array}{c}\text { coef. } \\
-1.862 \\
\end{array}$ & $\begin{array}{c}\chi^{2} \\
72.53^{* * *} \\
\end{array}$ & $\begin{array}{l}\text { coef. } \\
-1.150 \\
\end{array}$ & $\begin{array}{c}\chi^{2} \\
62.04 * * * \\
\end{array}$ & $\begin{array}{c}\text { coef. } \\
-1.139 \\
\end{array}$ & $\begin{array}{c}\chi^{2} \\
56.26^{* * *} \\
\end{array}$ & $\begin{array}{l}\text { coef. } \\
-2.853\end{array}$ & $\begin{array}{c}\chi^{2} \\
106.59 * * * \\
\end{array}$ \\
\hline
\end{tabular}

Notes: Estimated with conditional fixed-effects logit. The dependent variable is a binary variable equal to one if the managing director is changed in the respective year. Labor productivity is defined as the total sales over the total number of employees. Gross profit per employee is defined as the total sales less the costs of goods sold over the total number of employees. Return on assets is defined as the total sales less the costs of goods sold over the total assets. Size stands for the fixed assets. Performance after the first MD change in Panel B is a variable that is equal to the respective performance measure for all firm-years following the first managing director change in a given firm and zero otherwise. All variables are industry adjusted. The test of joint significance measures the total performance effect in the firms-years following the first managing-director change. $*, * *, * *$ denote significance at the $10 \%, 5 \%$ and $1 \%$ level, respectively. 


\section{References}

Barberis, N., Boycko, M., Shleifer, A., Tsukanova, N., 1996. How does privatization work? Evidence from the Russian shops. Journal of Political Economy 104 (4), 764-790.

Claessens, S., Djankov, S., 1999. Enterprise performance and management turnover in the Czech Republic. European Economic Review 43, 1115-1124.

Claessens, S., Djankov, S., 2000. Manager incentives and turnover of managers: Evidence from the Czech Republic. In Rosenbaum, E., Bönker, F., Wagener, H.J. (Eds.), Privatization, Corporate Governance and the Emergence of Markets. Macmillan Press Ltd, UK, pp. 171-188.

Cragg, M.I., Dyck, I.J.A, 1999. Management control and privatization in the United Kingdom. RAND Journal of Economics 30 (3), 475-497.

Denis, D.J., Denis, D.K., 1995. Performance changes following top management dismissals. Journal of Finance 50 (4), 1029-1057.

Djankov, S., Murrell, P., 2002. Enterprise restructuring in transition: A quantitative survey. Journal of Economic Literature 40, 739-792.

Dyck, I.J.A., 1997. Privatization in Eastern Germany: Management selection and economic transition. American Economic Review 87 (4), 565-597.

Earle, J.S., Estrin, S., 1998. Privatization, competition, and budget constraints: Disciplining enterprises in Russia, London Business School.

Fidrmuc, J., Fidrmuc, J., Horvath, J., 2002. Visegrad economies: Growth experience and prospects. Global Development Network: Global Research Project on Understanding Growth, manuscript, available at http://www.cerge.cuni.cz/pdf/gdn/grp_final_visegrad.pdf.

Fidrmuc, J.P., Fidrmuc, J., 2004. Fire the manager to improve performance? Managerial turnover and incentives after privatization in the Czech Republic. CEPR Discussion Paper No. 4351, Centre for Economic Policy Research, London. 
Frydman, R., Hessel, M., Rapaczynski, A., 2002. Why ownership matters? Entrepreneurship and the restructuring of enterprises in Central Europe. In: Fox, M., Heller, M. (Eds.), Corporate Governance Lessons from Transition Economy Reforms. Princeton University Press, Princeton.

Groves, T., Hong, Y., McMillan, J., Naughton, B., 1995. China's evolving managerial labor market. Journal of Political Economy 103 (4), 873-891.

Hermalin, B.E., Weisbach, M.S., 2003. Board of directors as an endogenously determined institution: A survey of the economic literature. FRBNY Economic Policy Review, 7-26.

John, K., Senbet, L.W. 1998. Corporate governance and board effectiveness. Journal of Banking and Finance 22, 371-403.

Laffont, J-J., Tirole, J., 1986. Using cost observation to regulate firms. Journal of Political Economy 94, $614-641$.

Linz, S.J., Krueger, G., 1998. Enterprise restructuring in Russia's transition economy: Formal and informal mechanisms. Comparative Economic Studies 40, 5-52.

McAfee, R.P., McMillan, J., 1987. Competition for agency contracts. RAND Journal of Economics 18 (Summer), 296-307.

McMillan, J., 1997. Markets in transition. In Kreps, D.M., Wallis, K.F. (Eds.), Advances in Economics and Econometrics: Theory and Implications. Cambridge University Press, Cambridge, pp. 210-239.

Pohl, G., Anderson, R.E., Claessens, S. Djankov, S., 1997. Privatization and restructuring in Central and Eastern Europe. World Bank Technical Paper No. 368, World Bank.

Roland, G., 2000. Transition and economics: Politics, markets, and firms. MIT Press, Cambridge, MA.

Warner, J.B., Watts, R.L., Wruck, K.H., 1988. Stock prices and top management changes. Journal of Financial Economics 20, 461-492.

Warzynski, F., 2003. Managerial change, competition, and privatization in Ukraine. Journal of Comparative Economics 31, 297-314.

Weisbach, M.S., 1988. Outside directors and CEO turnover. Journal of Financial Economics 20, 431-460. 


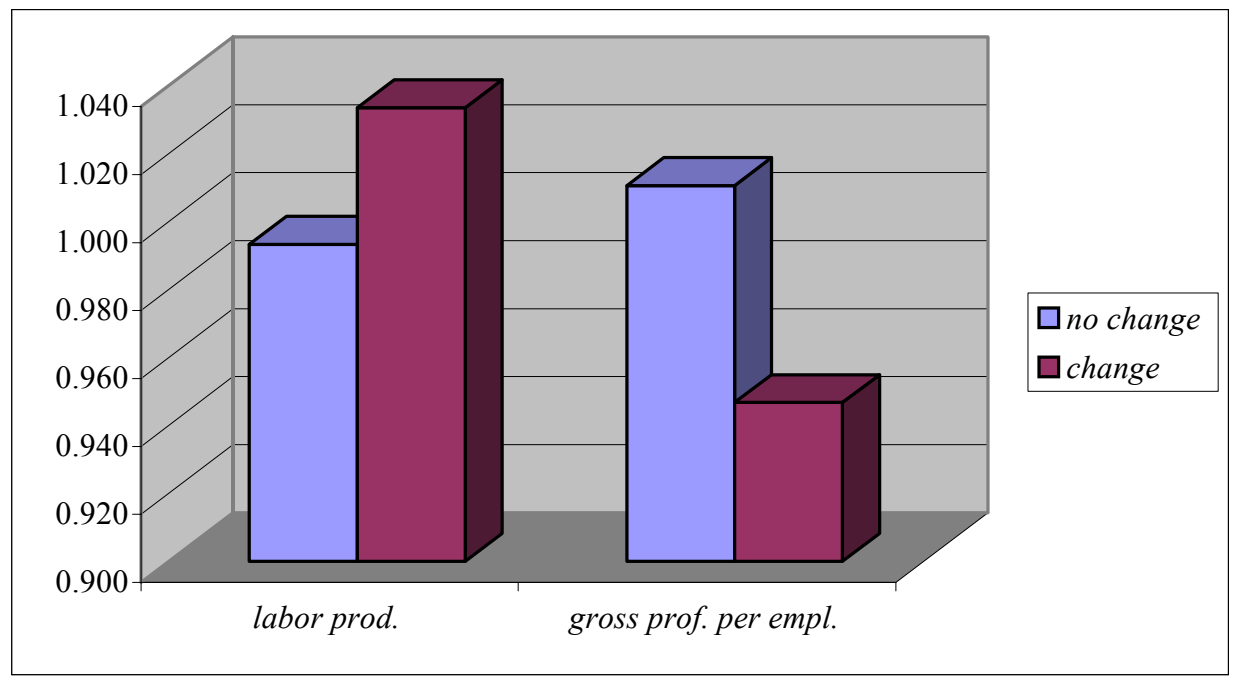

Figure 1: PAST PERFORMANCE: THE POOLED INCENTIVE EFFECT

Notes: This figure shows the overall relationship between performance in firm-years immediately preceding managing director change versus firm-years without a MD change in the following year. The data cover the period over 1994-98 for two performance measures: labor productivity and gross profit margin per employee. Both measures are industry adjusted (divided by industry average in each year). The indicated differences are not statistically significant. The number of observations is 3,082 and 617 for the 'no change' and 'change' groups, respectively. 


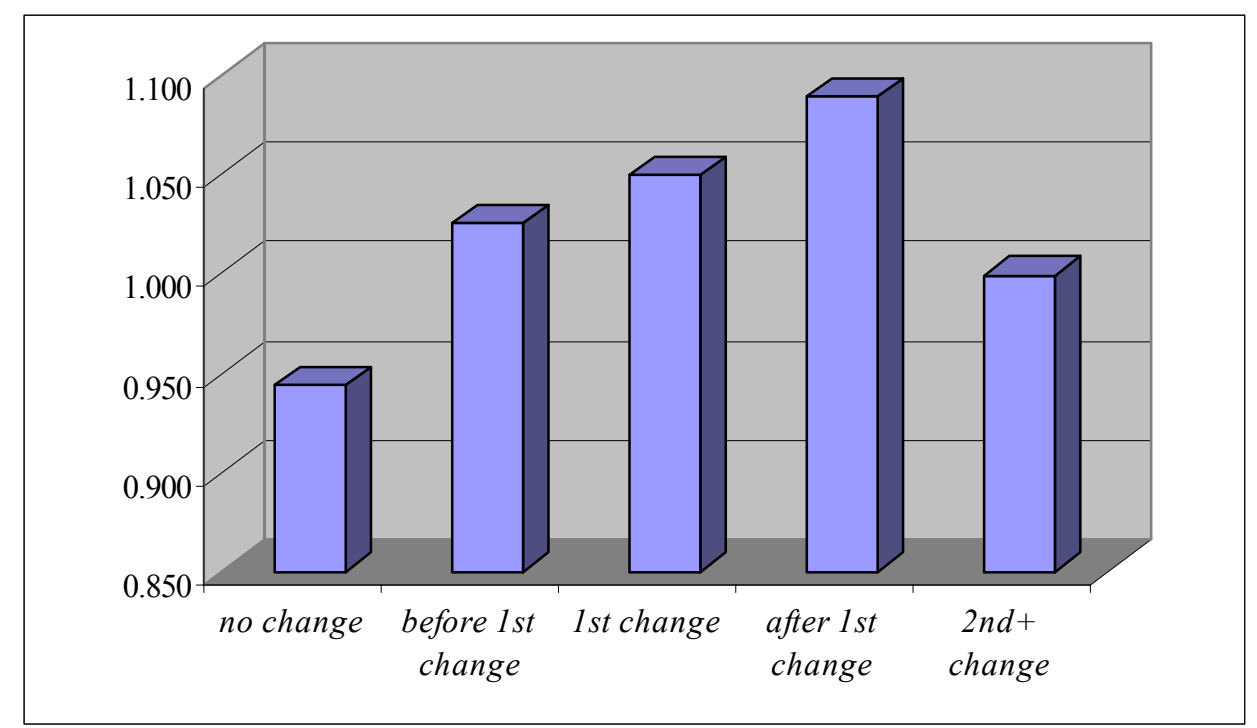

\section{FIGURE 2: NEW MANAGERS AND INCENTIVES: LABOR PRODUCTIVITY}

Notes: This figure shows labor productivity (industry adjusted) for five different groups of firm-year observations. No change $\left(1^{\text {st }}\right.$ bar) covers all firms (and then years) with no managing director change over 1994-98. It includes 1,684 observations. Before $1^{\text {st }}$ change ( $2^{\text {nd }}$ bar with 798 observations) covers all firm-years before the first change of the managing director after the privatization. $1^{\text {st }}$ change $\left(3^{\text {rd }}\right.$ bar with 420 observations) includes all firm-year observations with the first managing director change in the post-privatization period. The last two bars include only firm-year observations following the first change of the managing director. After $1^{\text {st }}$ change $\left(4^{\text {th }}\right.$ bar with 600 observations) covers all firm-year observations without a MD change that followed after the first change of the MD. $2^{\text {nd }}+$ change (the last bar, 197 observations) includes the firm-year observations with a MD change that was not the first one after the privatization. 


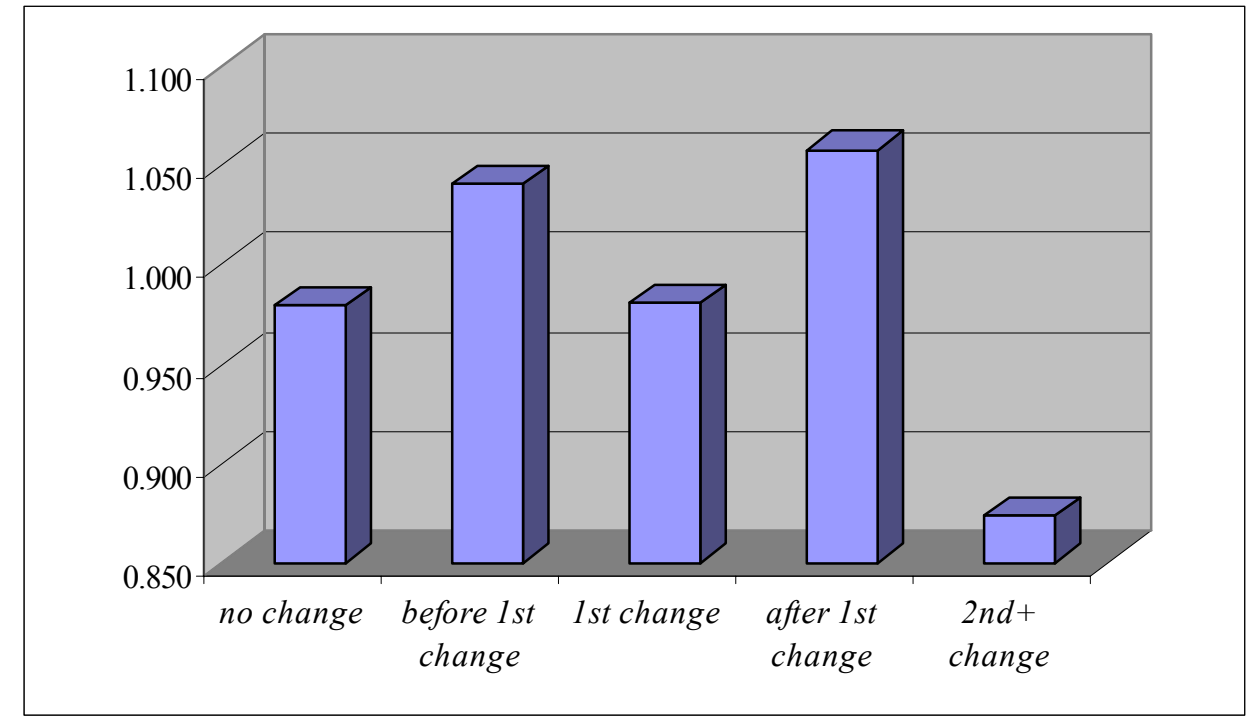

FIGURE 3: NEW MANAGERS AND INCENTIVES: GROSS PROFIT PER EMPLOYEE

Notes: This figure shows gross profit per employee (industry adjusted) for five different groups of firm-year observations. The groups ate as defined in Figure 2. 
TABLE 1: DESCRIPTIVE STATISTICS

\begin{tabular}{|c|c|c|c|c|c|c|c|}
\hline \multicolumn{2}{|c|}{ PANEL A (4109 observations) } & mean & minimum & $5^{\text {th }}$ perc. & median & $95^{\text {th }}$ perc. & $\max$ \\
\hline \multicolumn{2}{|c|}{ Total sales (CZK thousands) } & 808,304 & 411 & 26,110 & 220,694 & $3,190,962$ & $54,800,000$ \\
\hline \multicolumn{2}{|c|}{ Costs of goods sold (CZK thousands) } & 593,379 & 0 & 13,344 & 155,311 & $2,548,257$ & $29,500,000$ \\
\hline \multicolumn{2}{|c|}{ Gross profit margin (CZK thousands) } & 212,072 & $-1,922,689$ & 1,711 & 52,090 & 646,722 & $28,900,000$ \\
\hline \multicolumn{2}{|l|}{ Number of employees } & 833 & 4 & 71 & 320 & 2,593 & 49,701 \\
\hline \multicolumn{2}{|l|}{ Labor productivity } & 1,021 & 2 & 208 & 559 & 3,234 & 63,823 \\
\hline \multicolumn{2}{|c|}{ Gross profit per employee } & 202 & $-4,148$ & 8 & 156 & 573 & 2,990 \\
\hline \multicolumn{2}{|l|}{ Return on assets } & 0.237 & -2.532 & 0.007 & 0.211 & 0.537 & 3.290 \\
\hline \multicolumn{2}{|c|}{ Change of the managing director } & 0.165 & 0 & 0 & 0 & 1 & 1 \\
\hline \multicolumn{2}{|c|}{ PANEL B (3699 observations) } & mean & minimum & $5^{\text {th }}$ perc. & median & $95^{\text {th }}$ perc. & $\max$ \\
\hline \multicolumn{2}{|c|}{ Total sales (CZK thousands) } & 423,947 & 22,925 & 45,549 & 216,143 & $1,629,157$ & $3,384,868$ \\
\hline \multicolumn{2}{|c|}{ Costs of goods sold (CZK thousands) } & 320,371 & 4,696 & 26,512 & 151,372 & $1,202,408$ & $4,608,437$ \\
\hline \multicolumn{2}{|c|}{ Gross profit margin (CZK thousands) } & 103,575 & $-1,922,689$ & 4,582 & 50,641 & 418,044 & $1,589,126$ \\
\hline \multicolumn{2}{|l|}{ Number of employees } & 622 & 11 & 90 & 320 & 2,120 & 24,247 \\
\hline \multicolumn{2}{|l|}{ Labor productivity } & 896 & 10 & 231 & 531 & 2,721 & 23,353 \\
\hline \multicolumn{2}{|c|}{ Gross profit per employee } & 186 & $-4,148$ & 24 & 151 & 485 & 1,982 \\
\hline \multicolumn{2}{|l|}{ Return on assets } & 0.242 & -2.532 & 0.014 & 0.217 & 0.537 & 3.290 \\
\hline \multicolumn{2}{|c|}{ Change of the managing director } & 0.168 & 0 & 0 & 0 & 1 & 1 \\
\hline \multicolumn{2}{|c|}{ PANEL C (3699 observations) } & 1993 & 1994 & 1995 & 1996 & 1997 & 1998 \\
\hline \multicolumn{2}{|l|}{ Number of firms } & 459 & 815 & 822 & 814 & 759 & \\
\hline \multirow[t]{3}{*}{ Labor productivity: } & mean & 849 & 853 & 884 & 921 & 957 & \\
\hline & Median & 495 & 502 & 524 & 548 & 579 & \\
\hline & st. dev. & 952 & 936 & 917 & 1,206 & 1,037 & \\
\hline \multirow[t]{3}{*}{ Gross profit per empl.: } & mean & 181 & 184 & 174 & 177 & 213 & \\
\hline & Median & 147 & 148 & 148 & 147 & 168 & \\
\hline & st. dev. & 209 & 195 & 245 & 222 & 227 & \\
\hline \multirow[t]{3}{*}{ Change of the MD: } & mean & & $10.9 \%$ & $9.8 \%$ & $17.3 \%$ & $25.2 \%$ & $18.2 \%$ \\
\hline & Median & & 0 & 0 & 0 & 0 & 0 \\
\hline & st. dev. & & $31.2 \%$ & $29.8 \%$ & $37.8 \%$ & $43.4 \%$ & $38.6 \%$ \\
\hline \multicolumn{8}{|l|}{ PANEL D (866 firms) } \\
\hline \multicolumn{2}{|l|}{ Number of MD changes } & 0 & 1 & 2 & 3 & 4 & 5 \\
\hline \multicolumn{2}{|c|}{ Number of firms (frequency) } & $416(48.0 \%)$ & $313(36.1 \%)$ & $112(12.9 \%)$ & $21(2.4 \%)$ & $3(0.3 \%)$ & $1(0.1 \%)$ \\
\hline
\end{tabular}

Notes: All variables (except number of employees and change of the managing director) are in constant prices of 1993. Labor productivity is defined as the total sales over the total number of employees. Gross profit per employee is defined as the total sales less the costs of goods sold over the total number of employees. Return on assets is defined as the total sales less the costs of goods sold over the total assets. 
Table 2: The CEO Turnover / Past Performance Relationship

\begin{tabular}{|c|c|c|c|c|c|c|c|c|}
\hline \multirow{3}{*}{ Panel A: Pooled regressions } & \multirow{2}{*}{\multicolumn{2}{|c|}{$\begin{array}{c}\text { Labor } \\
\text { productivity }\end{array}$}} & \multirow{2}{*}{\multicolumn{2}{|c|}{$\begin{array}{c}\begin{array}{c}\text { Gross prof. per } \\
\text { employee }\end{array} \\
\text { Model } 2\end{array}$}} & \multirow{2}{*}{\multicolumn{2}{|c|}{$\begin{array}{c}\text { Return on assets } \\
\qquad \text { Model } 3\end{array}$}} & \multirow{2}{*}{\multicolumn{2}{|c|}{$\begin{array}{c}\text { Labor } \\
\text { productivity } \\
\text { growth }\end{array}$}} \\
\hline & & & & & & & & \\
\hline & coef. & s.e. & coef. & s.e. & coef. & s.e. & coef. & s.e. \\
\hline Performance (lagged) & -0.126 & 0.141 & -0.039 & 0.057 & 0.043 & 0.081 & 0.082 & .0124 \\
\hline Size (lagged) & -0.125 & 0.149 & -0.125 & 0.150 & -0.142 & 0.148 & 0.103 & 0.236 \\
\hline Fixed effects & yes & & yes & & yes & & yes & \\
\hline Year dummies & yes & & yes & & yes & & yes & \\
\hline \# of observations & 3699 & & 3699 & & 3699 & & 2841 & \\
\hline \# of firms & 866 & & 866 & & 866 & & 853 & \\
\hline$\chi^{2}$ & 94.97 & $* * *$ & 94.61 & $* * *$ & 94.42 & $* * *$ & 48.54 & $* * *$ \\
\hline \multirow[t]{2}{*}{$\begin{array}{l}\text { Panel B: First versus subsequent } \\
\text { changes }\end{array}$} & \multicolumn{2}{|c|}{ Model 5} & \multicolumn{2}{|c|}{ Model 6} & \multicolumn{2}{|c|}{ Model 7} & \multicolumn{2}{|c|}{ Model 8} \\
\hline & coef. & s.e. & coef. & s.e. & coef. & s.e. & coef. & s.e. \\
\hline Performance (lagged) & 0.379 & $0.176^{* *}$ & 0.267 & $0.103 * * *$ & 0.313 & $0.104 * * *$ & 0.520 & $0.181 * * *$ \\
\hline Performance after the first MD change & -2.324 & $0.195 * * *$ & -1.321 & $0.143 * * *$ & -1.457 & $0.144 * * *$ & -3.786 & $0.267 * * *$ \\
\hline Size (lagged) & 0.041 & 0.189 & -0.021 & 0.174 & -0.194 & 0.160 & 0.447 & 0.322 \\
\hline Fixed effects & yes & & yes & & yes & & yes & \\
\hline Year dummies & yes & & yes & & yes & & yes & \\
\hline \# of observations & 3699 & & 3699 & & 3699 & & 2841 & \\
\hline \# of firms & 866 & & 866 & & 866 & & 853 & \\
\hline$\chi^{2}$ & 314.87 & $* * *$ & 211.88 & $* * *$ & 224.29 & $* * *$ & 361.58 & $* * *$ \\
\hline $\begin{array}{l}\text { Test of joint significance: } \\
\text { perf. + perf. after } 1^{\text {st }} \mathrm{MD} \text { change }\end{array}$ & $\begin{array}{c}\text { coef. } \\
-2.703\end{array}$ & $\begin{array}{c}\chi^{2} \\
65.19^{* * *}\end{array}$ & $\begin{array}{c}\text { coef. } \\
-1.588\end{array}$ & $\begin{array}{c}\chi^{2} \\
48.06^{* * *}\end{array}$ & $\begin{array}{c}\text { coef. } \\
-1.144\end{array}$ & $\begin{array}{c}\chi^{2} \\
53.67 * * *\end{array}$ & $\begin{array}{c}\text { coef. } \\
-3.269\end{array}$ & $\begin{array}{c}\chi^{2} \\
119.03\end{array}$ \\
\hline
\end{tabular}

Notes: Estimated with conditional fixed-effects logit. The dependent variable is a binary variable equal to one if the managing director is changed in the respective year. Labor productivity is defined as the total sales over the total number of employees. Gross profit per employee is defined as the total sales less the costs of goods sold over the total number of employees. Return on assets is defined as the total sales less the costs of goods sold over the total assets. Size stands for the fixed assets. Performance after the first MD change in Panel B is a variable that is equal to the respective performance measure for all firm-years following the first managing director change in a given firm and zero otherwise. All variables are industry adjusted. The test of joint significance measures the total performance effect in the firms-years following the first managing-director change. $*$, **, *** denote significance at the $10 \%, 5 \%$ and $1 \%$ level, respectively. 